\title{
Membongkar Imperialisme dalam Kebijakan Pajak Usaha Mikro Kecil dan Menengah (UMKM)
}

\author{
Yuyung Rizka Aneswari ${ }^{1}$
}

\author{
${ }^{1}$ STIE Kesuma Negara Blitar, Jln. Mastrip No. 59, Kepanjen Kidul, Blitar, 66117, Jawa Timur, Indonesia
}

\section{A R T I C L E I N F O}

Article history:

Received 14 April 2018

Revised 10 Juni 2018

Accepted 23 Juli 2018

Keywords:

Keadilan, Kebijakan Pajak,

Kritis,Marhaenisme, UMKM

\begin{abstract}
A B S T R A C T
This article aims to criticize the fairness of the application of the final tariff income tax for MSME This research is in a critical paradigm using Sukarno's thinking Marhaenism as a tool to criticize. Marhaenisme has three basic values, namely Sosio Nasionalisme, Sosio Demokrasi dan Ketuhanan yang Maha Esa. The results show that taxation policy does not take into account the unique characteristics of SMEs, allegedly only concerned with a certain type of dolongan and loaded with the spirit of materialism. This research has a policy contraibution that provides a discourse for the government on a fair tax implementation scheme, especially for MSMEs.
\end{abstract}

\begin{abstract}
A B S T R A K
Artikel ini bertujuan untuk mengkritisi keadilan penerapan pajak penghasilan tarif final bagi UMKM Penelitian ini berada pada paradigma kritis menggunakan pemikiran Sukarno yakni Marhaenisme sebagai alat untuk mengkritisi. Marhaenisme memiliki tiga nilai dasar yaitu Sosio Nasionalisme, Sosio Demokrasi dan Ketuhanan Yang Maha Esa. Hasil penelitian menunjukkan bahwa kebijakan perpajakan tidak mempertimbangkan karakteristik unik UMKM, diduga hanya mementingkan dolongan tertentu dan sarat dengan semangat materialisme. Penelitian ini memiliki kontribusi kebijakan yakni memberikan wacana bagi pemerintah mengenai skema penerapan pajak yang adil terutama bagi UMKM.
\end{abstract}

\section{PENDAHULUAN}

Keputusan pemerintah menurunkan tarif pajak final UMKM dinilai tak banyak membantu dan memberikan insentif bagi UMKM (Masyrafina \& Budi, 2018). Sebelumnya pemerintah mengeluarkan peraturan yang cukup mengejutkan pada 1 Juli 2013 dengan menerapkan pajak 1\% bagi UMKM (Yusuf, 2013). Peraturan tersebut dituangkan dalam PP 46 tahun 2013 yang dinilai sebagai bentuk penindasan pemerintah dengan kedok legislasi penyederhanaan perhitungan PPh terhadap pengusaha kecil. Penyederhanaan perhitungan PPh hanya merupakan kata pemanis yang sebetulnya menjadikan pengusaha kecil yang selama ini termarjinalkan menjadi korban.

UMKM di Indonesia memiliki potensi yang sangat besar dan terbukti mampu bertahan dalam badai krisis moneter tahun 1997. Pada krisis global tahun 2008, UMKM juga justru menjadi penyelamat ekonomi nasional dari keterpurukan. Potensi UMKM dilihat dari tingkat pertumbuhannya juga menunjukkan grafik yang terus meningkat. Pertumbuhan jumlah UMKM dari tahun 2005 sampai tahun 2012 meningkat sekitar 20,2\% (BPS, 2016). Sayangnya terdapat miss match antara potensi yang tinggi dari UMKM dengan kepatuhan pajaknya. Penerimaan pajak total yang memiliki porsi $80 \%$ lebih terhadap APBN, kontribusi UMKM hanya sebesar kurang lebih 0,5\% (Ibrahim, n.d.). PerJuni 2013 jumlah UMKM adalah 55,2 juta, namun yang baru terdaftar Nomor Pokok Wajib Pajak (NPWP) hanya sekitar 13-16 juta (Martfianto \& Widyaiswara, 2013).

Rendahnya kepatuhan pajak UMKM ini disebabkan karena kebijakan pajak yang terlalu memberatkan mereka. Di negara lain terjadi hal serupa mengenai kebijakan perpajakan yang memberatkan bagi UMKM sehingga berpengaruh terhadap pertumbuhan sektor ini. Penelitian Mwangi \& Nganga (2006) menunjukkan UMKM di Nigeria yang memiliki potensi tinggi namun mengalami kesulitan besar karena kebijakan pajak yang memberatkan mereka. Rekomendasi yang diberikan oleh Mwangi \& Nganga (2006) adalah agar pemerintah memberikan kebebasan pajak bai UMKM yang baru berjalan.

\footnotetext{
${ }^{1}$ Corresponding author, email address: yuyung@stieken.ac.id
} 
Penelitian Atawodi \& Ojeka (2012) mengambil objek penelitian UKM yang ada di Nigeria mematahkan asumsi bahwa penerimaan pajak akan digunakan untuk kesejahteraan dan meningkatkan perekonomian rakyat. Temuan penelitian menunjukkan bahwa terdapat hubungan negatif antara penerimaan pajak dengan kemampuan UKM di Nigeria untuk bertahan dan mengembangkan bisnisnya. Kebijakan perpajakan bagi UKM di Nigeria dinilai sangat berat sebab tarif pajaknya yang tinggi, pajak berganda, peraturan perpajakan yang rumit dan kurangnya edukasi maupun informasi yang berkaitan dengan perpajakan (Atawodi \& Ojeka, 2012).

Kebijakan perpajakan yang berat dan justru mematikan UMKM tersebut, sebagaimana temuan penelitian di atas menjadi alasan rasional bagi UMKM untuk tidak mematuhi kebijakan perpajakan. Maka pada penelitian Ponorîcă \& Alsaedi (2015) merekomendasikan bahwa perlu dibuat kebijakan perpajakan yang sederhana dan meminimalkan biaya kepatuhan pajak. Beban pajak antara Usaha Kecil Menengah (UKM) dan perusahaan tidak boleh sama dan perusahaan yang besar seharusnya membayar beban pajak yang lebih tinggi Ponorîcă \& Al-saedi (2015).

Temuan penelitian sebelumnya menunjukkan bahwa UMKM di negara lain juga memiliki potensi yang tinggi namun mengalami kebijakan perpajakan yang sangat memberatkan. Kebijakan perpajakan inilah yang mampu menghambat perkembangan usaha UMKM. Hal serupa terjadi di Indonesia, UMKM di Indonesia mengalami kebijakan perpajakan yang tidak berkeadilan. pungutan pajak untuk perusahaan besar belum benar, usaha yang kecil malah ditarik pajak. Selain itu pungutan pajaknya juga mengabaikan kemampuan ekonomis UMKM, kondisi untung atau rugi tetap dipajaki.

Penelitian ini berusaha melakukan telaah kritis pengenaan PPh final bagi UMKM dengan menggunakan pemikiran Bung Karno yakni Marhaenisme. Berdasarkan penggambaran kondisi regulasi perpajakan bagi pengusaha kecil yang merupakan "wong cilik" atau kaum Marhaen, saya memandang bahwa regulasi PPh bagi pengusaha UMKM sama sekali tidak berpihak pada pengusaha UMKM. Analisa kritis yang menurut saya paling tepat adalah menggunakan salah pemikiran Bung Karno ${ }^{1}$ yakni Marhaenisme ${ }^{2}$ untuk mengkonstruksi dialektika ${ }^{3}$ antara otoritas pajak sebagai pengusaha dan kaum Marhaen pengusaha UMKM. Tujuan penggunaan pemikiran Marhaenisme ini adalah mengikuti misi dari ajaran ini, yakni memperjuangkan kesejahteraan kaum kecil.

Penelitian ini memberikan dua kontribusi yakni kontribusi kebijakan dan kontribusi teori. Kontribusi kebijakan artikel ini adalah memberikan pertimbangan bagi pemerintah mengenai kebijakan yang perlu disusun sebagai skema perpajakan yang tepat bagi UMKM. Kontribusi teori artikel ini adalah menambah khasanah ilmu mengenai teori yang berkaitan dengan kepatuhan pajak

\section{METODE PENELITIAN \\ Pemilihan Paradigma Penelitian}

Penelitian ini menggunakan paradigma kritis dengan menggunakan pemikiran Bung Karno yaitu Marhaenisme sebagai pisau analisis. Asumsi dasar teori kritis adalah: 1) ilmu sosial tidak hanya memahami ketidakadilan suatu distribusi kekuasaan beserta distribusi resources, namun berupaya membantu menciptakan kesamaan dan emansipasi kehidupan, 2) pendekatan teori kritis memiliki keterikatan moral dalam rangka mengkritik status quo beserta membangun masyarakat yang lebih adil (Muhadjir, 2000:198; Tashakkori \& Teddlie, 2010:122). Proses berpikir kritis ini menuntut untuk berpikir terbuka dalam mengumpulkan, menganalisa dan evaluasi terhadap informasi relevan untuk selanjutnya merumuskan pertanyaan yang terkait dengan masalah dan mengajukan ide-ide serta secara efektif berkomunikasi dengan pihak lain (Duron, Limbach, \& Waugh, 2006).

1 Soekarno mendapat berbagai julukan antara lain Bung Karno, Sang Proklamator dan Putra Sang Fajar

2 KBBI : Marhaenisme adalah paham yang bertujuan memperjuangkan nasib kaum kecil untuk mendapatkan kebahagiaan hidup

3 KBBI : Ajaran HEGEL yang menyatakan bahwa segala sesuatu yag terdapat di alam semesta itu terjadi dari hasil pertentangan antara dua hal dan yang menimbulkan hal lain. 
Penentuan paradigma perlu untuk meninjau segi ontologi dan epistemologi. Secara ontologi, realitas tidak bersifat tunggal dan kebenaran bukan merupakan suatu yang pasti dan terukur serta secara epistemologi dunia sosial merupakan hal yang kompleks dan dinamis. Realitas adalah suatu konstruksi sosial yang diciptakan oleh individu, namun kebenaran suatu realitas sosial yang bersifat pasti atau terukur, berlaku sesuai konteks spesifik yang relevan oleh pelaku sosial (Bungin, 2012:81). Maka berdasarkan pertimbangan tersebut kami berpandangan bahwa paradigma kritislah yang akan dapat menyoroti, memberikan pemahaman dan perubahan yang menuju arah positif dari peraturan perpajakan yang tidak adil dari sudut pandang UMKM.

\section{Marhaenisme sebagai Pisau Analisis}

Pemikiran Bung Karno mengenai Marhaenisme merupakan satu pemikiran beliau yang tak lekang jaman. Sepanjang masalah sosial yang terjadi saat ini terkait dengan kolonialisasi, imperialisme dan kapitalisme maka jawabannya adalah pemikiran Bunga Karno (Marhaenisme) sangat tepat digunakan untuk memecahkannya.

Marhaenisme mengangkat masalah penghisapan dan penindasan rakyat kecil yang terdiri dari kaum tani miskin, petani kecil, buruh miskin, pedagang kecil, kaum melarat Indonesia oleh para kapitalis, tuan tanah, rentenir dan golongan-golongan penghisap lainnya. Marhaenisme dilahirkan dan dikembangkan antara tahun 1930-1933 dengan melakukan pembelaan terhadap "kaum proletarnya" Indonesia, yakni kaum Marhaen. Pada saat itu, kepentingan rakyat adalah tujuan akhir dari segala-galanya. Menurut Soekarno, masa itu mayoritas penduduk Indonesia, entah itu buruh, tukang becak, tukang asongan, nelayan, hingga insinyur hidup seperti Pak Marhaen. Mereka memiliki alat produksi, namun hal itu tak menolong mereka untuk hidup layak. Akhirnya, ajaran ini diberi nama Marhaenisme.

Inti ajaran Marhaenisme sebetulnya adalah ekstraksi dari Pancasila yang dimampatkan menjadi tiga (3) sila (trisila) yakni 1) Ketuhanan Yang Maha Esa, 2) sosio nasionalisme dan 3) sosio demokrasi (Sutoro, n.d.; Tanya, Parera, \& Lena, 2015:37). Sosio Nasionalise adalah karakter atau ciri nasionalisme, nasionalisme yang muncul harus berwatak sosial tidak merasa bangsanya besar (chauvinis). Nasioalisme tidak berwatak ekspansif, sangat menghargai perbedaan antar bangsa dan menghendaki persamaan derajat antar bangsa. Sosio Nasionalisme juga menghargai persamaan derajat antar bangsa.

Sosio Demokrasi dilatarbelakangi pengaruh kuat demokrasi liberal yang dianut negara Barat seperti Amerika, Inggris dan Prancis. Sosio demokrasi juga tidak hanya menuntut persamaan di bidang politik. Sosio demokrasi juga harus diterapkan dalam bidang ekonomi. Artinya sistem perekonomian Indonesia harus dibangun atas semangat gotong royong bukan semangat yang kuatlah yang menang. Di bumi Indonesia negara harus mengatur agar yang kuat membantu yang lemah. Karena kompetisi secara bebas akan menghasilkan ketimpangan yang sangat dalam. Sosio demokrasi menjadi misi utama ajaran ini yakni terbitnya kesejahteraan sosial pada seluruh kaum Marhaen yang mengalami penindasan dn penghisapan di Indonesia.

Ketuhanan Yang Maha Esa yang merupakan value yang terkandung dalam ajaran Marhaenisme ini menjadi jalan bagi saya untuk merumuskan suatu usulan keadilan perpajakan dari sudut pandang kontraktual (yang berpihak pada pengusaha UMKM) serta keadilan dari sudut pandang Ketuhanan. Yakni membawa Tuhan dan Agama dalam memandang dan merumuskan keadilan. Keadilan yang ingin dicapai adalah keadilan hakiki sebagaimana yang ditulis oleh Alim (2015) dalam Simposium Nasional Perpajakan (SNP) tahun 2015 di Universitas Trunojoyo Madura, bahwa adil adalah segala sesuatu yang berada pada tempatnya yang mampu memberikan kepuasan (horizontal) serta yang utama adalah dekat dengan ketaqwaan (vertikal), artinya jauh dari konsep materialisme.

Proses penurunan sebuah pemikiran menjadi metodologi dan metode terinspirasi dari Kamayanti (2016: 171) yakni dengan menyesuaikan konteks isu penelitian yang sedang dilakukan peneliti dengan asumsi realitas yang melandasi pemikiran tersebut. Asumsi yang melandasi teori Kritis Marhaenisme adalah: 1) UMKM diibaratkan sebagai kaum Marhaen atau wong cilik yang harus diperjuangkan kesejahteraannya, 2) UMKM sedang tertindas dan mengalami penghisapan melalui kebijakan perpajakan, 3) Keadilan hanya akan tercapai apabila kebijakan perpajakan kembali pada misi ajaran ini yakni kesejahteraan sosial. Perumpamannya adalah yang kuat membantu yang lemah. Pihak yang kuat adalah pemerintah dan wajib pajak (WP) perusahaan besar dan pihak yang lemah adalah UMKM. Asumsi ini dapat diturunkan menjadi sebuah metodologi kritis dengan melihat bahwa saat ini melalui kebijakan perpajakan UMKM sedang mengalami 
imperialisme, penindasan dan penghisapan. Kebijakan perpajakan dinilai bukan untuk kepentingan rakyat bersama, namun sebagai bentuk generating untuk meningkatkan peneriman pajak. Sehingga kebijakan yang lahir tidak berfokus pada tujuan mensejahterakan rakyat. Maka nilai dalam Marhaenisme digunakan untuk mengkonstruksi keadilan kebijakan perpajakan dengan mendasarkan kepentingan pada kaum Marhaen alias wajib pajak UMKM.

\section{Unit Analisis dan Metode}

Unit analisis penelitian ini adalah kebijakan pajak penghasilan yang dituangkan melalui PP 46 bagi UMKM. Data penelitian ini berasal dari berbagai literatur, data atau dokumen yang terkait dengan tema besar penelitian. Kami juga melakukan wawancara dengan beberapa informan. Pemilihan informan berdasarkan kemudahan kami mengakses dan kesesuaian latar belakang mereka yang dapat menjawab pertanyaan penelitian.

Klasifikasi informan dalam penelitian ini adalah konsultan pajak, pegawai pajak, akademisi, dan pengusaha UMKM. Nama dan instansi informan bukan merupakan nama sebenarnya, sesuai dengan permintaan dari informan. Daftar informan tersaji dalam tabel 1.1.

Tabel 1.1

Informan Penelitian

\begin{tabular}{|c|c|c|c|}
\hline No & Subjek Informan & Latar Belakang Informan & Keterangan \\
\hline 1 & Arum & $\begin{array}{l}\text { Akademisi Perpajakan dan } \\
\text { pemilik UMKM }\end{array}$ & $\begin{array}{l}\text { Diskusi dilakukan oleh peneliti secara } \\
\text { insidentil karena yang bersangkutan } \\
\text { adalah rekan kerja }\end{array}$ \\
\hline 2 & Agung & Peternak Ayam Petelur & $\begin{array}{l}\text { Wawancara dilaksanakan dari Juli } \\
\text { 2017- Januari 2018. Pemilihan waktu } \\
\text { dikarenakan sesuai dengan awal } \\
\text { berdirinya usaha ini dan peneliti } \\
\text { mendampingi masalah pelaporan } \\
\text { keuangannya }\end{array}$ \\
\hline 3 & Liz & $\begin{array}{l}\text { Pengusaha Souvenir Owner Si } \\
\text { Kuprit }\end{array}$ & $\begin{array}{l}\text { Wawancara dilakukan secara } \\
\text { insidental dalam keadaan santai di }\end{array}$ \\
\hline 4 & Gema & $\begin{array}{l}\text { Deputy of Chairman for IPR } \\
\text { Facilitation and Regulation at } \\
\text { Badan Ekonomi Kreatif RI }\end{array}$ & $\begin{array}{l}\text { belakang panggung oleh peneliti saat } \\
\text { informan (Liz dan Gema) menjadi } \\
\text { narasumber seminarRegional Ekonomi } \\
\text { Kreatif di Gedung Graha Patria Blitar } 7 \\
\text { Oktober 2017. Peneliti saat itu menjadi } \\
\text { moderator seminar. }\end{array}$ \\
\hline
\end{tabular}

\section{Sumber: Peneliti}

Pengumpulan dan analisis data dilakukan secara bersamaan. Proses pengumpulan data, analisis data, dan penulisan laporan merupakan proses yang saling berhubungan dan simultan (Creswell, 2007:150). Kesulitan wawancara adalah terdapat beberapa hal yang menyebabkan kami tidak mendapat jawaban yang sesuai, mungkin karena alasan pribadi informan. Sehingga kami melakukan alternatif teknik probing yakni: 1) peneliti memberikan kesan mengerti dan mendengarkan, 2) membuat situasi wawancara menyenangkan, dan 3) menghindari rasa takut responden untuk berpartisipasi (Hartono, 2014: 116-117).

\section{ANALISIS DATA DAN DISKUSI \\ Potensi UMKM di Indonesia.}

UMKM di Indonesia memiliki peran yang sangat signifikan pada perekonomian nasional. UMKM di Indonesia juga terbukti tangguh mampu bertahan dalam kondisi krisis (Hartarto \& Muhajir, 2013). Hal ini yang menjadikan UMKM termasuk dalam objek pajak yang potensial. UMKM merupakan salah satu bentuk usaha yang paling sesuai bagi Indonesia sebab sifatnya yang padat karya dan selalu memanfaatkan potensi daerah sekitarnya (Aneswari, Darmayasa, \& Yusdita, 2015). Pertumbuhan UMKM di Indonesia makin meningkat tahun 2012 sebesar 20,2\% serta memberikan peningkatan sumbangan PDB 54\% dari tahun 2005-2012 (BPS, 2016). Data tahun 2012 juga menunjukkan bahwa sumbangan UMKM terhadap PDB meningkat 9,9\% dan pertumbuhan 
penyerapan tenaga kerja meningkat 2,41\% (BPS, 2016).

Hal yang perlu diingat oleh pemerintah adalah jangan hanya melihat sumbangan siginifikan UMKM terhadap perekonomian Nasional yang miss match dengan kepatuhan pajaknya. Di sisi lain pemerintah perlu melihat bahwa sumbangan yang besar itu berasal dari banyak UMKM kecilkecilnya. Pemberlakuan peraturan perpajakan yang berpengaruh pada mekanisme perpajakan bagi sektor ini sangat perlu diperhatikan. Jangan sampai pemerintah menerbitkan pajak yang tidak mendukung perkembangan UMKM.

\section{Munculnya Sistem Perpajakan dan Imperialisme terhadap Rakyat Indonesia}

Sejarah munculnya imperialisme kapitalisme di Indonesia diawali saat penjajahan Belanda dengan menerapkan sistem tanam paksa di pulau Jawa (Bulkin, 1984:10). Masa itu seluruh rakyat dipaksa untuk menanam tanaman produksi dan seluruh hasilnya harus diserahkan pada penjajah dengan harga amat sangat murah. Sistem ini berhasil "terpaksa" ditaati oleh petani pribumi karena didukung oleh pemimpin daerah yang mulai dari bupati hingga kepala desa yang bermental pengecut. Mereka mematuhi skema kejam Belanda dengan menerbitkan aturan yang melegitimasi aturan kejam cultuurstelsel tersebut.

Rakyat menyerahkan hasil panen yang dibayarkan sebagai pajak dalam bentuk natura. Melalui tanam paksa sistem pertanian dihancurkan dengan memaksa menanam komoditas perdagangan. Akibatnya saat itu banyak rakyat kelaparan karena tidak cukup hasil panen dari tanaman pangan untuk mereka konsumsi.

Bung Karno menyatakan bahwa imperialisme merupakan suatu sistem yang didasari atas nafsu dan kerakusan. Sistem muncul karena sebuah kebijakan yang dikeluarkan pemerintah. Sistem yang imperialisme dihasilkan dari sebuah kebijakan yang tak berpihak pada rakyat. Kebijakan perpajakan yang diperuntukkan bagi UMKM merupakan salah satu contoh konkret bentuk imperialisme negara terhadap rakyat.

UMKM di Indonesia memiliki potensi yang sangat baik sehingga bisa jadi suatu saat menjadi saingan berat bagi perusahaan besar. UMKM memiliki banyak produk andalan yang sangat bisa diterima oleh konsumen internasional. Perekonomian nasional telah terselamatkan oleh keberadaan UMKM salah satunya penyerapan tenaga kerja sebab UMKM usaha padat karya. Produksi UMKM seringkali juga merupakan produksi yang menggunakan bahan baku yang merupakan potensi daerah setempat.

Kebijakan perpajakan bagi UMKM diawali dengan dikeluarkannya kebijakan pajak 1\% dari omset yang dikeluarkan pada Juli 2013 kemudian per 1 Juli 2018 tarif berubah menjadi 0,5\% dari omset (PP No. 23 Tahun 2018). Penurunan tarif ini bukan merupakan solusi bagi UMKM sebab terdapat hal yang jauh lebih dibutuhkan oleh UMKM untuk berkembang selain menjadikan UMKM yang berada di sektor informal menjadi formal dengan memiliki NPWP.

Hasil wawancara dengan seluruh informan pemilik UMKM dan dikonfirmasikan dengan sebuah perkumpulan UMKM di Blitar terdapat beberapa kesulitan dan keterbatasan yang harus mereka hadapi. Kendala pertama adalah di awal usahanya mereka kesulitan untuk melakukan distribusi hasil produksinya. Proses untuk melakukan pengembangan usaha tidak banyak mendapat dukungan dari pihak pemerintah. Salah satu contohnya adalah informan Arum yang mengalamai kesulitan saat mengurus dokumen ekspor untuk produk- produk mebel antiknya ke Eropa. Hampir seluruh UMKM yang kami wawancara memiliki kemampuan dalam pencatatan sangat minim sehingga seringkali lemahnya manajemen ini berdampak pada tidak bisa mengukur perkembangan usaha mereka.

Meskipun pemerintah menurunkan tarif pajak final menjadi 0,5\%, namun beberapa UMKM tidak dapat memperkirakan omset mereka karena rendahnya disiplin dalam aktivitas pencatatan dan produksi UMKM berdasarkan pesanan. Ada masamasa ramai pesanan, namun juga ada masanya pesanan sepi. Kenaikan harga bahan bakar yang tak disangka- sangka juga makin memperberat mereka memperoleh untung, sedangkan melalui pajak final laba atau rugi bukan menjadi pertimbangan perhitungan pajak.

Hukum pajak di Indonesia menganut adagium lex speciali derogat lex generali. Artinya hukum yang khusus akan mengesampingkan hukum umum yang ada di atasnya. Begitu juga dengan kebijakan pajak bagi UMKM. Sebelum ditetapkan tarif final dari omset, terdapat perhitungan tarif pajak menggunakan norma yang dihitung beradsarkan penghasilan netto, jenis usahanya dan letak kotanya. Penggunaan norma dalam perhitungan pajak penghasilan bertujuan untuk memudahkan WP Orang Pribadi (OP) yang melaksanakan pekerjaan bebas yang memiliki peredaran bruto tertentu untuk menghitung penghasilan nettonya. Peraturan mengenai norma terbaru tertuang pada 
Per-17/PJ/2015. Hal yang perlu digarisbawahi di sini adalah apakah hukum pajak baru bagi UMKM ini telah melaksanakan mandat hukum yang ada di atasnya? Pajak penghasilan berdasarkan UU No 36 tahun 2008 dihitung dari penghasilan bersih.

\section{Dimana Posisi Pemerintah dilihat dari Marhaenisme Sosio Nasionalisme.}

Sosio Nasionalisme berdasarkan pemahaman Marhaenisme adalah semangat nasionalisme dengan tidak merasa bangsa sendiri adalah bangsa yang paling besar dan menghargai adanya perbedaaan. Nasionalisme tidak berwatak ekspansif dan menginginkan persamaan derajat. Tambahan isme dalam sosio nasionalisme artinya menunjukkan sebuah ideologi perlawanan rakyat akan sebuah sistem yang menindas dan memelaratkan rakyat (Bararoh, 2013: 57-58).

Sosio Nasionalisme pada konteks penelitian ini dapat diartikan sebagai perlawanan UMKM akan kebijakan perpajakan yang tak berkeadilan dan memiskinkan. Kebijakan perpajakan UMKM dianggap tidak menjadi jalan keluar untuk meningkatkan kesejahteraan namun justru sebaliknya. Berkaitan dengan hal ini saya melakukan diskusi secara insidental dengan dua informan bernama Liz dan Gema. Diskusi terjadi saat Liz membuka obrolan tentang pajak $E$ Commerce:

“...waah bentar lagi pajak E-Commerce sudah diberlakukan...Pajak yang khusus UMKM aja masih terasa berat..Saya pribadi jadi merasa sudah namanya usahanya kecil mikro pula, makin merasa kecil kalau urusannya sama pajak" (Liz)

"Yaa..semua kebijakan pemerintah pasti tujuannya baik loo mas..Gak mungkinlah ditetapkan tanpa pertimbangan mateng. Bekraf memahami juga beratnya pajak bagi UMKM, makanya ini lagi ngajukan ke pemerintah supaya UMKM yang baru berdisi dikasih waktulah beberapa tahun gitu baru dipajaki. Biar mereka secara finansial mandiri dahulu " (Gema)

Kemudian diskusi berlanjut ketika ada pertanyaan dari peserta seminar pemilik UMKM.

"saya memiliki usaha yang sudah lumayan lancar berjalan, artinya pesanan sudah banyak. Tapi masih sewa kita tempat usahanya...Pertanyaan saya pak, ini kan saya mau mengembangkan usaha saya. Sayangnya harus ada jaminan yang diminta bank, tapi saya tempat usaha aja sewa. Mau pinjam keluarga juga mereka tidak yakin mau kasih pinjaman. Solusinya bagaimana ini pak kalau sulit aksesnya untuk dapat kredit usaha?" (Peserta Seminar)
Sebelum pemberlakuan kebijakan pajak final pada UMKM pemerintah memperhatikan kemudahan usaha bagi UMKM. UMKM masih menghadapi kesulitan dalam pemasaran, pembukuan dan akses permodalan. Akses permodalan ini merupakan hal yang penting agar UMKM dapat mengembangkan usahanya.

Sistem bisnis UMKM cenderung tradisional ini yang menjadi pandangan pemerintah. Karena dari kacamata pemerintah UMKM dinilai tradisional atau kuno sehingga perlu ada langkah kebijakan agar UMKM menjadi bisnis yang modern dan masuk dalam sektor formal. Berangkat dari pandangan ini lantas UMKM dipaksa mengikuti aturan pemerintah agar mereka meninggalkan culture yang terlanjur mereka anut dan yakini agar memasuki kriteria pemerintah supaya dapat mengakses layanan pemerintah dalam kemudahan usaha mereka.

Pandangan pemerintah ini jika dilihat dari Sosio Nasionalisme tentu sama sekali tidak menghargai perbedaan dan keadaan spesial UMKM yang tradisional dan seringkali sangat kental dengan local wisdom dimana UMKM berdiri. Kebijakan pajak khusus UMKM telah dikeluarkan pemerintah agar UMKM memasuki sektor formal, namun hanya dapat menggandeng sedikit UMKM. Data terbaru Badan Pusat Statistik (BPS) Juni 2013 menunjukkan dari 50,2 juta UMKM baru 13 juta sampai 16 juta yang memiliki NPWP (Martfianto \& Widyaiswara, 2013). Pertanyaannya adalah melihat fakta seperti itu apakah pemerintah tetap bersikeras memaksakan sebuah kebijakan supaya UMKM mengikuti pola yang diinginkan pemerintah atau sebaliknya pemerintah yang beradaptasi terhadap keadaan UMKM? Sebaiknya pemerintah mencoba menghargai perbedaan yang ada pada UMKM dengan membuat adaptasi sistem perbankan dan kebijakan yang sesuai dengan kondisi UMKM.

\section{Sosio Demokrasi}

Sosio Demokrasi tidak menghendaki adanya kompetisi secara bebas dan di bumi Indonesia kebijakan yang menyangkut orang banyak tidak boleh mengorbankan rakyat kecil. Mahalnya biaya berpolitik di Indonesia, membuka pintu bagi pengusaha untuk berperan dalam kancah politik. Kekuasaan uang yang membuat pengusaha ini lantas memiliki pengaruh kuat pada penguasa, sehingga mampu mempengaruhi pengambilan keputusan pada langkah kebijakan yang diambil.

Apabila memperhatikan awal munculnya imperialisme dari sejarah aturan tanam paksa, 
maka satu hal yang menjadi benang merah adalah adanya kekuasaan yang besar dari pengusaha yang mampu menundukkan pemerintah. Kekuasaan pengusaha tersebut mampu mempengaruhi pemerintah untuk mengambil sebuah kebijakan yang hanya menguntungkan bisnisnya, tanpa mempertimbangkan pihak lain yang akan menderita akibat kebijakan yang tak berkeadilan. Perselingkuhan antara penguasa dengan pengusaha dinarasikan secara gamblang oleh Studwell (2009) yang mengisahkan para taipan Asia (Godfather) yang menguasai perekonomian salah satunya di Indonesia. Para Godfather ini adalah segelintir konglomerat yang memiliki kekuasaan luar biasa yang mampu membius penguasa untuk membuat berbagai aturan atau kebijakan yang menguntungkan bisnis Godfather ini.

"Saya ini mulai menjalankan ternak ayam petelur mau 6 bulan ini. sudah mulai berproduksi telurnya, cuman dari awal keluarkan modal bikin kandang sampai sekarang belum balik modal. Berat rasanya kalau masih dipajaki gini... Nyapo kok ndak yang usaha- usaha gede sering ngemplang pajak itu yang diurusi?

Saya aja masih ikut Pak Sis (Peternak terbesar di Blitar). Mulai dari ayamnya, pakannya ambil dari sana. Memang sedikit lebih mahal, cuman jaminannya kualitas bibit ayam dan pakan sudah terjamin. Kita peternak belajaran gini ndak pusing- pusing menyadur komposisi pakan biar telur itu kualitasnya bagus."(Agung)

Sosio Demokrasi menginginkan sebuah kebijakan yang berpihak pada rakyat, bukan pada segelintir golongan. Memperhatikan kutipan wawancara pada sub bab sosio nasionalisme di atas, yang dibutuhkan oleh UMKM adalah kebijakan yang memiliki insentif bagi pengembangan usaha mereka. Kebijakan pajak penghasilan bagi UMKM tujuannya adalah merangsang UMKM untuk memasuki ranah formal agar menjadi pembayar pajak untuk memenuhi target penerimaan pajak. Namun yang dibutuhkan UMKM sebenarnya adalah sebuah kebijakan yang fokusnya pada ekonomi kerakyatan. Yakni kebijakan yang mampu menjadi solusi shortfall sekaligus solusi keberlanjutan jangka panjang. Kebijakan shortfall yang dibutuhkan UMKM antara lain adalah pertama masalah pendanaan yang sistemnya mengadaptasi kondisi UMKM yang seringkali tidak memiliki aset maupun sistemnya bisnisnya seringkali masih tradisional. Masalah pendanaan ini sangat sulit dijangkau oleh UMKM yang masih menyewa tempat dan tidak memiliki aset seperti yang disampaikan oleh informan peserta seminar. Kedua terkait dengan infrastruktur dan logistik (Ananti, 2018). Solusi jangka panjangnya adalah konsistensi pemerintah agar tidak membuat kebijakan yang berubah- ubah serta komitmen pemerintah untuk membuat kebijakan khusus bagi UMKM agar UMKM dapat naik kelas. Agar tidak terus menyandang sebutan kecil dan mikro lagi seperti yang disampaikan informan Liz.

\section{Ketuhanan yang Maha Esa}

Prinsip Ketuhanan yang Maha Esa dalam Marhaenisme adalah dijalankannya etika Berketuhanan. Kaitannya dengan kebijakan perpajakan adalah tidak menganut paham materialisme (Swasono, 2010: 99), atau pengejaran target penerimaan pajak dan mengesampingkan rakyat kecil. Hubungan antara pemerintah dengan rakyat kemudian menjadi dangkal hanya tentang penyerahan materi berupa pajak yang mampu disetorkan ke kas negara.

Sudut pandang pemerintah adalah hanya melihat jumlah UMKM yang makin meningkat dari tahun ke tahun dan sumbangannya pada Produk Domestik Bruto (PDB) yang tinggi, namun persentase porsinya pada penerimaan pajak sangat kecil. Memang jika melihat data BPS jumlah UMKM dari tahun 2005 sampai tahun 2012 meningkat sekitar 20,2\% (BPS, 2016). Sumbangan UMKM pada PDB juga tak main- main pada tahun 2012 meningkat 9,9\% dari tahun sebelumnya (BPS, 2016). Namun pemerintah perlu mempertimbangkan bahwa sumbangan sebesar itu berasal dari kumpulan jutaan pelaku UMKM. Prinsip yang harus diperhatikan dalam kebijakan perpajakan adalah prinsip keadilan, baik keadilan vertikal dan keadilan horizontal (Jan, 2013:27; Rosdiana \& Irianto, 2014:161-162). Artinya setiap kebijakan perpajakan perlu mempertimbangkan kemampuan secara ekonomis apakah wajib pajak mampu membayarkan pajaknya.

Meskipun telah diturunkan tarif pajak final bagi UMKM menjadi 0,5\% masih belum memberikan insentif baik bagi UMKM. Kebijakan perpajakan dengan tarif final masih belum memenuhi prinsip keadilan perpajakan, peraturan ini tidak mencerminkan keadilan vertikal, karena tidak mempertimbangkan kemampuan bayar, karena dasar tarif pajaknya berasal dari peredaran bruto maka dalam keadaan rugi akan tetap dipajaki. Kebijakan ini juga melanggar hak dasar untuk memperoleh Penghasilan tidak Kena Pajak (PTKP) bagi wajib pajak, sebagai biaya minimal 
untuk dapat bertahan hidup. Sehingga jika melihat dari sudut pandang Alim (2015) kebijakan pajak ini tidak mampu memberikan kepuasan pada WP (keadilan secara horizontal) dan tidak dekat dengan ketaqwaan sebab bersemangatkan materialisme yang tinggi (keadilan vertikal).

Kritikan pada artikel ini tidak merta memandang buruk DJP mengingat sebuah lembaga swasta pernah memberikan penghargaan pada DJP sebagai institusi dengan layanan terbaik (Kemenkeu, 2016). Peneliti masih optimis akan langkah DJP untuk terus berbenah setelah kasus Gayus sebab fitrah manusia adalah memiliki kebutuhan untuk taat pada Sang Pencipta (divine consciousness) (Aneswari \& Darmayasa, 2016). Sehingga asumsi bahwa manusia hanyalah makhluk yang rasional harus ditinjau ulang, sebab fitrah manusia adalah makhluk religius yang memiliki keinginan untuk taat pada Penciptanya (Fidiana, Triyuwono, Djamhuri, \& Achsin, 2013). Kesadaran Ilahi ini akan mempengaruhi nilai yang dipegang dalam menjalankan kehidupan termasuk praktik profesional dalam pekerjaan. Sebagaimana dalam penelitian Darmayasa \& Aneswari (2015) yang menunjukkan bahwa konsultan pajak yang memegang teguh nilai religiusitas akan menciptakan layanan profesional yang kondusif dengan memberikan edukasi perpajakan pada kliennya.

\section{SIMPULAN, IMPLIKASI, SARAN DAN KETERBATASAN}

Keputusan pemerintah untuk menurunkan tarif pajak final bagi UMKM sepertinya masih belum memberikan insentif yang menunjukkan posisi pemerintah yang Pro dengan pelaku UMKM. Hal yang perlu dijunjung tinggi dalam setiap kebijakan pajak adalah prinsip keadilan. Keadilan kebijakan yang ditujukan pada UMKM kemudian dilihat dari kacamata pemikiran Sukarno yakni Marhaenisme. Marhaenisme memiliki tiga prinsip yang merupakan ekstraksi Pancasila yakni 1) Sosio Nasionalisme, 2) Sosio Demokrasi dan 3) Ketuhanan Yang Maha Esa.

Sosio Nasionalisme artinya pemerintah perlu menghargai perbedaan UMKM dengan usaha berskala nasional di Indonesia. Pemerintah telah mengakui peran besar dan potensi UMKM, maka perlu juga mempertimbangkan karakteristik unik UMKM. Kebijakan yang diberlakukan pada UMKM agar mereka mampu masuk dalam ranah formal sebaiknya juga mengadaptasi karakteristik UMKM. Bukan sebaliknya UMKM yang dipaksa mengikuti pola pemerintah.
Sosio Demokrasi artinya langkah kebijakan yang diambil pemerintah harus mempertimbangkan kepentingan rakyat, bukan hanya golongan tertentu. Mahalnya biaya berpolitik di Indonesia memunculkan pola dan budaya money politic, sehingga setiap penguasa yang mencalonkan diri untuk menjadi pemimpin pasti ada ikut campur pengusaha besar yang memiliki kekuatan materi. Hal ini yang kemudian melatarbelakangi adanya ikut campur pengusaha pada pengambilan keputusan kebijakan oleh pemerintah agar selalu menguntungkan bisnisnya (Studwell, 2009: 15). UMKM memerlukan sebuah kebijakan yang mampu memberikan insentif bagi mereka untuk dapat mengakses pembiayaan, infrastruktur dan bahan baku serta mendukung mereka agar dapat naik kelas.

Ketuhanan yang Maha Esa dalam Marhaenisme memegang prinsip bahwa kebijakan pemerintah harus berazaskan agama (dekat dengan ketaqwaan) bukannya semangat materialisme. Penerbitan kebijakan pajak tarif final bagi UMKM ini telah mencerminkan semangat materialisme untuk mengejar target penerimaan pajak tanpa mempertimbangkan keadilan vertikal dan horizontal. Pengenaan tarif final ini dinilai tidak memenuhi prinsip keadilan tersebut, sebab dalam kondisi untung maupun rugi tetap dipajaki serta melanggar hak WP untuk memperoleh PTKP.

Penulisan artikel harapannya mampu memantik peneliti lain untuk melakukan penelitian terkait kritik terhadap suatu kebijakan yang tak berkeadilan yang seringkali dinilai sudah mapan karena telah dikukuhkan secara sah dalam sebuah aturan baku. Artikel ini perlu dikembangkan dengan mengkritik dan membangun konsep pajak yang berkeadilan bagi UMKM dengan kacamata yang lebih utuh seperti menggunakan Pancasila.

\section{REFERENSI}

Alim, M. N. (2015). Pajak dan Prinsip Keadilan. Madura: Disampaikan dalam Simposium Nasional Perpajakan (SNP) 5, Universitas Trunojoyo Madura 12 November 2015.

Ananti, R. (2018). Insentif Pajak UMKM 0,5 \% Dinilai Belum Pro Usaha Mikro. Retrieved June 30, 2018, from http://www.klinikpajak.co.id/berita+detail/ ?id=berita + pajak +-

+ insentif + pajak + umkm $+0 \% 2 \mathrm{C} 5 \% 25+$ dinilai $+\mathrm{b}$ elum+pro+usaha+mikro

Aneswari, Y. R., Pajak Berlandaskan Tat Twam Asi. In P\& Darmayasa, I. N. (2016). Konsep Kepatuhan ertemuan Masyarakat Akuntansi 
Multiparadigma Indonesia Nasional 4 (TEMAN4). Jakarta: Universitas Mercubuana, 14-15 April 2016.

Aneswari, Y. R., Darmayasa, I. N., \& Yusdita, E. E. (2015). Perspektif Kritis Penerapan Pajak Penghasilan 1\% Pada UMKM. In Simposium Nasional Perpajakan 5 Fakultas Ekonomi Universitas Trunojoyo Madura, 12 November 2015. Madura: Universitas Trunojoyo, 12 Nopember 2015.

Atawodi, O. W., \& Ojeka, S. A. (2012). Relationship between Tax Policy, Growth of SMEs and the Nigerian Economy. International Journal of Business and Management. http://doi.org/10.5539/ijbm.v7n13p125

Bararoh, T. (2013). Konstruksi Pengelolaan Keuangan Daerah Berbasis Marhaenisme(Studi Pada Pemerintah Kota Batu dan Kota Surakarta). Disertasi tidak dipublikasikan Universitas Brawijaya.

BPS. (2016). Tabel Perkembangan UMKM pada Periode 1997 -2013. Retrieved from bps.go.id

Bulkin, F. (1984). Kapitalisme, Golongan Menengah dan Negara: Sebuah Catatan Penelitian. Prisma, (2), 1-39.

Bungin, H. M. B. (2012). Penelitian Kualitatif: Komunikasi, Ekonomi, Kebijakan Publik, dan Ilmu Sosial Lainnya (Kedua). Jakarta: Prenada Media Group.

Creswell, J. W. (2007). Qualitative Inquiry E Research Design Choosing among Five Approaches (2nd ed.). USA: Sage Publications Inc.

Darmayasa, I. N., \& Aneswari, Y. R. (2015). The Ethical Practice of Tax Consultant Based on Local Culture. In Book of Conference Proceedings 2nd Global Conference on BusinessESocial Sciences 17th-18th September 2015 Bali, Indonesia (p. 169).

Duron, R., Limbach, B., \& Waugh, W. (2006). Critical Thinking Framework For Any Discipline. International Journal of Teaching and Learning in Higher Education, 17(2), 160-166. Retrieved from http:/ / www.isetl.org/ijtlhe/pdf/IJTLHE17(2 ).pdf\#page $=89$

Fidiana, Triyuwono, I., Djamhuri, A., \& Achsin, M. (2013). Non-Compliance Behavior In The Frame Of Ibn Khaldun. In Seventh Asia Pasific Interdisciplinary Research in Accounting onference, Kobe 26-28 July 2013 (pp. 1-18).

Hartarto, A., \& Muhajir, A. (2013). Pemberdayaan Koperasi dan UMKM dalam Rangka Peningkatan Perekonomian Masyarakat. Jakarta: Komisi VI DPR RI.
Hartono, J. (2014). Metodologi Penelitian Bisnis Salah Kaprah dan Pengalaman-Pengalaman (6th ed.). Yogyakarta: BPFE Yogyakarta.

Ibrahim, S. (n.d.). Pengenaan PPh Final untuk Wajib Pajak dengan Peredaran Bruto Tertentu, Sebuah Konsep Kesederhanaan Pengenaan PPh untuk Meningkatkan Voluntary Tax Compliance. Pusat Kebijakan Pendapatan Negara - Badan Kebijakan Fiskal. Retrieved from www.kemenkeu.go.id/sites/defaults/files/K ajian PPh Final UMKM_PKPN.pdf

Jan, T. S. (2013). Pengadilan Pajak Upaya Kepastian Hukum dan Keadilan Bagi Wajib Pajak. Bandung: PT. Alumni.

Kamayanti, A. (2016). Metodologi Penelitian Kualitatif Pengantar Religiositas Keilmuan. Jakarta: Yayasan Rumah Peneleh.

Kemenkeu. (2016). DJP Raih Penghargaan Service Quality Award 2016. Retrieved December 12, 2016,from https://www.kemenkeu.go.id/publikasi/ber ita-unit/djp-raih-penghargaan-servicequality-award-2016/

Martfianto, R., \& Widyaiswara. (2013). Pajak 1\% untuk UMKM : Hadiah atau Hukuman? Retrieved October 30, 2016, from http:/ / www.bppk.kemenkeu.go.id/publikasi /artikel/167-artikel-pajak/14634-pajak-1untuk-umkm-hadiah-atau-hukuman

Masyrafina, I., \& Budi, R. (2018). Asosiasi UMKM: Penurunan Pajak Final tak Cukup Membantu. Retrieved April 20, 2018, from https://www.republika.co.id/berita/ekonom i/korporasi/18/03/21/p5xaoz415-asosiasiumkm-penurunan-pajak-final-tak-cukupmembantu

Muhadjir, N. (2000). Metodologi Penelitian Kualitatif. Yogyakarta: Rake Sarasin.

Mwangi, M., \& Nganga, I. (2006). Taxation and SME's Sector Growth. Asian Journal of Business and Management Sciences, 2(3), 1-7.

Ponorîcă, A. G., \& Al-saedi, A. H. J. (2015). The Importance of Taxation Systems for SME Tax Compliance. In Proceeding of the 9th International Management Conference "Management and Innovation For Competitive Advantage", November 5th-6th, 2015, Bucharest, Romania (pp. 129-136).

Rosdiana, H., \& Irianto, E. S. (2014). Pengantar Ilmu Pajak Kebijakan dan Implementasi di Indonesia. Jakarta: PT Raja Grafindo Persada.

Studwell, J. (2009). Asian Godfathers (Menguak Tabir Perselingkuhan Pengusaha dan Penguasa). 
Jakarta.

Sutoro. (n.d.). Marhaenisme. Retrieved February 26, 2016,fromhttp:/ /gmni.ft.ugm.tripod.com/ma rhaenisme.html

Swasono, S.-E. (2010). Ekspose Ekonomika: Mewaspadai Globalisasi dan Pasar Bebas Ekonomi (Revised\&Ex). Yogyakarta: UGM, Pusat Studi Ekonomi Pancasila (PUSTEP).

Tanya, B. L., Parera, T. Y., \& Lena, S. F. (2015).

Pancasila Bingkai Hukum Indonesia. Yogyakarta: Genta Publishing.
Tashakkori, A., \& Teddlie, C. (2010). Handbook of Mixed Methods in Social \& Behavioral Research (Terjemahan). Yogyakarta: Pustaka Pelajar.

Yusuf, E. M. (2013). Membedah Aturan Pajak Penghasilan Terbaru Bagi UMKM. Retrieved September 16, 2015, from http:/ / keuanganlsm.com/membedah-aturanpajak-penghasilan-terbaru-bagi-umkm/ 